\title{
The State of Conflict Prevention in France
}

\author{
Julie Fournier
}

\begin{abstract}
This article provides a quick overview of the state of conflict prevention in France. It examines the origin of the debate, the role played by France in this field, and the obstacles hindering the development of an effective preventive diplomacy capability in Europe. Conflict prevention is a relatively new discussion in France that is fuelled by the frustration from the failure in the Yugoslav crisis and the new focus of the government to develop a new security architecture in Europe, mainly through the European Union. Current actions, however, already reveal the difficulties that impede the development of an effective capacity of preventive diplomacy in Europe. Some of these difficulties result from the idea of prevention in general, while others are more specific to the situation in France which is characterized by the absence of an official definition as well as by internal quarrels between academic, politicians and the military as to the potential and implementation of conflict prevention. However, the author argues that the critical perspective proposed by French intellectuals and scientists could, in the long run, contribute to a more accurate understanding of conflict prevention.
\end{abstract}

\section{Précis}

Cet article fournit un résumésuccint de l'état où en est la prévention de conflits en France. Il examine l'origine du débat, le rôle joué par la France dans ce secteur, et les obstacles restreignant le développement $d$ 'une diplomatie préventive efficace en Europe. La question de la résolution de conflit est un débat, relativement nouveau en France, alimenté par la frustration engendrée par l'échec

Julie Fournier is a PhD Candidate at the Institut d'Etudes Politiques, Paris, France. She has MA in Political Science, Laval University, Quebec, Canada. dans la crise yougoslave et par l'attention renouvellée portée par le gouvernement au développement d'une architecture nouvelle de la sécurité en Europe, principalement via la Communauté Européenne. Les actionsen cours, cependant, révèlent déjà les difficultés entravant le développement d'une capacitéde diplomatiepréventive en Europe. Certaines de ces difficultés tiennent à ce qu'est l'idée de prévention en général, tandis que d'autres problemes sont plus particuliers d la situation hexagonale, qui se caractérise par l'absence d'une définition officielle $d u$ phénomène, autant que par un ensemble de querelles internes entre universitaires, politiques, et militaires sur les potentialités et la mise en place de la prévention de conflits. Malgré tout, l'auteure présente une argumentation selon laquelle la perspective critique, proposée sur la question par les intellectuelset les scientifiques français, pourrait, à long terme, contribuer d̀ une compréhension plus adéquate de la question de la prévention de conflits.

\section{Introduction}

In Western states as well as in international institutions, the concept of conflict prevention is giving rise to increasing discussion and research. If the idea is not exactly new-sharing characteristics and linkages with the broader notion of conflict resolutionthe tremendous changes provoked by the end of the Cold War give to the concept both a new meaning and new opportunities. Until recently, however, the idea has been largely the prerogative of the Anglo-Saxon world, as the Francophone, and France, in particular, have remained outside of the debate. Things are slowly changing as the Europeans begin to demonstrate a certain interest in the concept. During the last year or two, a few articles have been dedicated to conflict prevention and some conferences and workshops were organized among European security organizations and within academic circles. Particularly in France, various research institutes as well as governmental authorities have started to work on the idea. The goal of this short article is to draw a broad portrait of the state of conflict prevention in France. The origin of the interest manifested in the concept, France's role and initiatives in this area, and the many difficulties hindering the development of an effective preventive diplomacy strategy in Europe, will be briefly examined.

\section{The Origin of the Debate}

The renewed interest in conflict prevention in the international sphere looks to be mainly a conjunctural phenomenon. As Michael S. Lund observes, four trends are at the origin of this evolution:

... the emergence of a new, more cooperative international milieu; the sobering experience of international intervention in already advanced conflicts; the prospect of more threats to international stability; and the growing economic and political constraints on governments' exercise of foreign policy.

France is no exception to this tendency. However, two additional factors influence the growing interest in conflict prevention in France, namely, the particularly bitter feeling left in the wake of the Yugoslav conflict, and the Chirac government's recent prioritizing of certain policy directions in an effort to better define France's foreign policy.

The unsuccessful measures launched by the international community to prevent or, at least, manage most of the post-Cold War conflicts, and in particular the incapacity of international institutions to prevent the Yugoslav crisis and the genocide in Rwanda, provoked in France an im- 
portant debate characterized by a strong sentiment of culpability. Mutual accusations among military, policymakers and intellectuals (who, in this country, play a major role on the public scene), dominate the post-conflict phase. In fact, politicians, scholars and the military are still analyzing the causes of the Yugoslav failure. The latter two actors notably perceive the attitude manifested by the politicians at the beginning of the conflict as having served as an incentive for the warlike policy of Slobodan Milosevic, and assert that their procrastination is responsible for the deterioration of the situation. However, in spite of these accusations, there is a general consensus that something better could have been done to prevent the eruption of these two conflicts, in which France was strongly committed politically and militarily (being at one moment the main troop contributor in Bosnia). The assumption that some military as well as diplomatic measures could have been adopted in order to dissuade the utilization of force has encouraged the French to launch a brainstorming process on the notion of conflict prevention, and on the way it could be defined and implemented.

This movement towards the development of the concept coincides with another important evolution on the international scene resulting from the end of the Cold War, namely the need to elaborate a new European security policy. France wishes to play a major role in this process following the orientation adopted by François Mitterand which sought to make France, along with Germany, one of the major pillars of the European Union. The policy of the Chirac government, reminiscent of De Gaulle's conceptions, reflects a long-standing ambition to give to European states greater independence as regards the maintenance of peace on the continent. This approach coincides in France with the recent desire to restructure the French Army as well as French foreign policy towards Africa. The achievement of these goals implies the strengthening of European security organizations such as the Western
European Union (WEU) or the European Union (EU), ${ }^{2}$ as well as the development of a preventive diplomacy capability proper to Europe. In the European context of a rapid decline in defence spending and an important restructuring of national armed forces, this goal seems far from being reached. Nevertheless, France is strongly pushing in that direction. The preceding trends determine the role and initiatives taken by France in the field of conflict prevention.

\section{France's Role and Initiatives}

Although the idea of prevention is articulated and developed within the Council of Europe as well as in the Organization for Security and Cooperation in Europe (OSCE), the idea is also discussed within the European Union where France has been one of its strongest supporters. Convinced of the need todefine a new security structure for Europe, and confident that Europe has to build its own defence and security capacity mainly through exclusively European institutions such as the WEU or the EU, France is now trying to gather support for this idea and has proposed the creation of a Crisis Prevention Centre within the European Union.

Launched by former Prime Minister Michel Rocard and addressed to the European Parliament, the French initiative seeks to establish a collective analysis unit within the EU that would work in conjunction with NGOs, universities and research institutes, as well as with the United Nations and other regional organizations. The Centre would be aimed at early political intervention through the collection of information, its analysis, and its communication to the European Parliament. The European Parliament could then make recommendations on how it might intervene in a crisis, or launch various initiatives of political pressure, notably political condemnations or economic sanctions. The general objective behind the project is clearly to "... counter the political cost of ignoring warnings ... and to replace general appeals by substantiated recommen- dations for preventive action: 'There is this threat and, after appropriate analysis, we think this should be done and will cost ...'"3 In other words, the unit seeks to modify the actual decision-making procedure by providing objective recommendations to political leaders. This procedure is currently subject to evaluations by national chanceries and the new procedure would minimize their influence. Conceived to complement existing bodies involved in conflict prevention in the UN as well as in the OSCE, the Centre would, among other things, monitor countries in the area of human rights and detect situations that might constitute a threat to European security.

Yet while the project may appear valuable, its implementation is hindered by many obstacles. In fact, little progress has been made in the establishment of the unit officially called the "European Union Analysis Centre for Active Crisis Prevention." The Union adopted a $\$ 1$ million ECU budget in order to study the conditions for the creation of the Centre. ${ }^{4}$ Nevertheless, it is still the object of a debate between the states of the Union and remains, for the moment, inoperative. The evasiveness of the Maastricht Treaty (especially of its Article 5), ${ }^{5}$ as well as the reluctance of certain countries (especially the neutral members of the Union) to engage their troops in military interventions, precludes significant progress. Actually, the more concrete initiative launched by the EU in the field of conflict prevention consists of a declaration concerning the will of the Union to develop an intervention capability in conflicts occurring in Africa (DG8). ${ }^{6}$

\section{The Numerous and Persistent Obstacles}

Many obstacles impede the development of an effective capacity for preventive diplomacy in Europe. While some of them are characteristic of the general problems raised by the concept of conflict prevention itself, others are specific to Europe or to the political situation existing in France. 
A large number of obstacles are related to the development of conflict prevention in general. In fact, consensus on this matter can be said to exist among scientists and diplomats, as has been observed and enunciated in various reports and essays carried out mainly by members of the AngloSaxon community. ${ }^{7}$ In France, Maurice Bertrand, member of the UN Joint Inspection Unit, has been one of the first to address the problem, and has reached the same conclusions. ${ }^{8}$ Specifically, the main difficulties hampering conflict prevention in general include the absence of a common definition of the concept, the shortcomings existing in social and conflict theories, notably concerning the causes of war, and the gap that exists between intellectuals and practitioners. The success of preventive interventions is also dependent upon, as Maurice Bertrand and of what their contribution to this field should be. This historical context impedes the development of a cohesive European strategy in the field of conflict prevention. Europe's incapacity in this respect was revealed by its inertia in the face of the crisis that recently erupted in Albania. If the concurrence existing between the various European multilateral institutions constitutes an obstacle to a rapid intervention, the absence of a common vision represents an even more important difficulty. This issue, which has dramatic regional consequences, also has endogenous causes, as the debate existing in France illustrates.

Aside from the general tendency, an important confusion prevails in France concerning the definition of conflict prevention and preventive diplomacy. As it is the case elsewhere and primarily within the UN, the concepts tend

\section{Specifically, the main difficulties hampering conflict prevention in general include the absence of a common definition of the concept, the shortcomings existing in social and conflict theories, notably concerning the causes of war, and the gap that exists between intellectuals and practitioners.}

emphasizes rightly, the degree of cooperation between the conflicting parties, as well as on the political will of the states dominating the so called "international community."

Alongside these general factors of obstruction stand other obstacles proper to Europe. The journey towards an effective preventive diplomacy capability in the region is indeed hindered by the difficulties encountered in forging unity and establishing common ground among political entities characterized by historical commitments to defend their ancestral traditions and their national interests. In spite of the important evolutions on the continent since the last World War and the irreversible progress made toward the construction of Europe, European states (especially the more powerful of them) remain reluctant to cede part of their sovereignty, and still have different conceptions of security to encompass an excessive number of activities, ranking from classical diplomacy to peace enforcement, and including also humanitarian aid and preventive peacekeeping missions. In contrast to some Anglo-Saxon experts who prefer a restrictive definition of prevention, ${ }^{9}$ the French continue to use a broad conception of the idea, and tend to be suspicious towards specific measures such as preventive peacekeeping deployment. While this type of intervention has been cited excessively by some as a very promising and useful tool in order to prevent violent conflicts, many French scholars as well as high level military officials are of the opinion that its potential is impossible to measure. They also suggest that political pressures seem more important than military means of conflict prevention. Furthermore, French experts argue that even if violence erupts, military deployment will not beable to prevent further conflict escalation.

In the same spirit, many French experts and officials are reluctant to embrace the idea of developing a rapid reaction capability within the framework of the UN as proposed by a group of states under the chairmanship of the Netherlands and Canada. They assert that there already exists a rapid mobilization capacity of the armed forces within developed states, citing their own country as an example. France can deploy within $\mathbf{4 8}$ hours an important and self-sufficient contingent for multipurpose interventions. In their opinion, the creation of a rapid reaction capability unit in the UN raises not only important problems of command but also the very question of its mandate. Without a clear political direction, the instrument could be the object of misuse. In summary, two elements characterize the French debate over conflict prevention: the relatively broad vision of the idea shared by intellectuals and officials, and the important infighting related to who should act in this field.

Indeed, a broad conception of conflict prevention dominates the French political scene. While international interventions related to this idea can have specific targets and objectives such as deploying troops to prevent an existing conflict from degenerating, or monitoring elections, the French seem to insist rather on the long term dimension of conflict prevention. According to this view, prevention is more than simply an emergency intervention intended to prevent violence. Rather, it is deeply related to the social factors of conflict, and thus has to address the roots of international and internal disputes through a series of long-term and more diffuse instruments, such as economic consolidation and democracy building. This perspective is reflected in the importance given by the French to the role that can be played by the European Union in this field, as well as in a concrete French initiative that gave birth to the European Pact on Stability. Concluded with the nations of the former Soviet block, it engages 
them to resolve their disputes concerning minority problems through a diplomatic system of round-tables and treaties of mutual guarantees, which seems so far to work well. The French conception therefore implies that the notion of prevention has to be proactive rather than conservative. More than a simple act of diplomacy which in a sense tends to maintain the status quo, prevention has to be a "transformative action" looking forward to changing the existing international order. Instead of working on "actors," it should work on "situations." 10

The French perspective, while minimizing the short-term aspect of conflict prevention which is the more frequently used because of the inher- ized French society for many centuries. On the one side, different views exist between the military, intellectuals and NGOs concerning the meaning that should be given to the idea of prevention, the latter two segments being more ambitious and enthusiastic concerning the potential of the concept. The lack of reflection within the main French political parties or in the various state agencies worsens the difficulties created by the absence of a coherent vision. On the other side, quarrels exist among the military, the academics and the NGOs, each one looking to impose its view, as well as blaming the others for the failures encountered so far in various situations. While the intellectuals denounce the

More than a simple act of diplomacy which in a sense tends to maintain the status quo, prevention has to be a "transformative action" looking forward to changing the existing international order. Instead of working on "actors," it should work on "situations."

ent reluctance of the states to intervene in situations that do not seem urgent or in which their national interests are not immediately threatened, suggests nevertheless that more substantial efforts have to be given to the study of conflict and especially to the factors and processes responsible for the eruption of violence between different collectivities. Progress in this field depends, as specialists also have observed, on the links that can be established between intellectuals and practitioners, as one of the most significant difficulties related to conflict prevention is the gap between social knowledge and action. This is particularly a problem in France which does not hesitate to speak out at an international action, but, in the end, often has problems translating its message into clear action. Therefore, even if French academics were to come to the right conclusions regarding a conflict, the rhetoric may not necessarily translate into reality.

Indeed, the French political and academic arenas are dominated by sectarian views and parish-pump politics, illustrating a trend that has character- inertia of the political leaders in various crises, the military accuses the intellectuals as well as the politicians of failing to back their strong words with action. They assert that they are not given the means and the necessary autonomy to realize their mission. Many NGO representatives also had the impression that they had been used to the detriment of their credibility and their impartiality in various situations. They uphold that the evasiveness of the statesmen forced them to negotiate with war criminals and, in a sense, rendered their actions a contributing factor to the extension of conflicts.

Before it is able to take on the leading role it desires in the development of a European capacity for preventive diplomacy, France will first have to overcome its own internal fights. Better relations among decision makers, intellectuals, the military, and practitioners are needed. These might come about through reinforced cooperation between governing authorities and research institutes interested in conflict theory, between the government and NGOs who have experience and are often the first to act as well as the last to remain in a situation of conflict, and cooperation between the politicians and the military, if greater autonomy is granted to the latter. As these observations reveal, decision makers are involved in every aspect of the question. Despite their current rhetoric concerning the importance of conflict prevention, they are still ignorant of the potential of the concept and reluctant to mobilize the will and the resources necessary to make the idea a tangible reality. Therefore, important efforts to heighten their awareness must be launched by intellectuals and practitioners working in this field. While the broad definition of the concept and the infighting still prevailing may impede this process, the critical attitude adopted by many French intellectuals and high-level military officials can contribute, in a long-term perspective, to building a more accurate comprehension of the concept and of its potential, encouraging everyone to free themselves from a rhetoric that leads to nothing except the devaluation of the idea. Conflict prevention has to be understood as a useful but limited tool of intervention. The mixed success registered so far in conflict prevention activities in Europe, and the important obstacles remaining before an efficient capability can emerge, show that the concept must not be used as a moral alibi by decision makers to conceal their idleness. Rather, its place is as a tool whose potential is to moderate.

\section{Conclusion}

If we can be pleased that European nations and France, in particular, have started to be interested in conflict prevention, we are forced to admit that an effective European capability in this field will remain elusive until four conditions are met. First, a better definition of the concept is needed. Second, the EU'S mandate in this field, along with that of other European security organizations, has to be clarified. As an incomparable cohesive force, the Union certainly has a role to play in preventing violence on the European continent. As a matter of fact, its attractiveness seems to have contributed to 
the success registered so far by some of the operations conducted by the OSCE. ${ }^{11}$ Its role might be effective in a long-term and more diffuse perspective. Third, the development of a military capacity for Europe is essential in order to bring a rapid response to preconflictual situations. So far, the question remains open. Finally, as one of the pillars of Europe, France can influence the debate positively if it is able to overcome its proper internal quarrels.

\section{Notes}

1. Michael S. Lund, Preventing Violent Conflicts: A Strategy for Preventive Diplomacy, Washington D.C., United States Institute of Peace, 1996, 8.

2. In March 1997, an initiative in that sense was taken by France and Germany when the two states launched a plan to transform the EU into a defence alliance through the incorporation of the WEU. Tom Buerkle, "Make the EU a Defence Alliance? Debate Deepens Security Policy Rifts." International Herald Tribune, Friday March 28 1997, 5.

3. Wolfgang Biermann and Martin Vadset, "Peacekeeping Principles in a Civil WarLike Conflict. Windows of Opportunity and Realistic Options in Former Yugoslavia 1991-1993-1995," DANORP 2nd UN Commanders Workshop, Report of a Conference held in Copenhagen Denmark 12-14 April 1996, Copenhagen, DanishNorwegian Research Project on UN Peacekeeping, 1996, 21.

4. The Centre, Institut de prevention des crises would be driven to be particularly interested by conflicts occurring in Africa. See Maurice Bertrand, "Le concept de prévention des conflicts." Politique étrangère, avril 1997.

5. The fifth article (or titre in French) of the Maastricht Treaty, although enunciating the goals of the Common Foreign and Security Policy of the European Union (CFSP), does not mention specifically the establishment of an early warning capability for the Union. The objectives defined in article J.1, paragraph 2 are quite large and the means by which they can be implemented remain vague and subject to the good will of the national governments. This interpretation of the Treaty provisions are detailed in E. Zoller "Dispositions concernant une politique, étrangère, et de securité, commune." In Vlad Constantinesco, Robert Kovar et Denys Simon (dir.), Trait, sur L'Union Européenne. Commentaire article par article.
Paris Economica, 1995, 781-812. They are also suggested by Reinhardt Rummel "The European Union's Politico-Diplomatic Contribution to the Prevention of Ethno-National Conflict." In Abram Chayes and Antonia H. Chayers (eds.) Preventing Conflict in the Post-Communist World. Washington, DC: The Brookings Institute, 1996, 197-236. For Rummel, "... when the CFSP was designed, during 1991, a large part of the new conflict-ridden world had not yet unfolded ... The Treaty ... reflects change, but only a first stage ... The provisions on CFSP therefore mention the strategic fields of adaptation, but most of the provisions are more an extrapolation of the line of evolution of EPC than a qualitatively fresh start," 200. For an exact account of the role of the EU in conflict prevention, please refer to Rummel's analysis.

6. This information was obtained from a short presentation by the French "chargé de mission" at International Alert during a one-day workshop on conflict prevention held in Paris January 3, 1997.

7. For an exhaustive and pertinent analysis of the question, one can refer to the book of Michael S. Lund, Preventing Violent Conflicts. A Strategy for Preventive Diplomacy.

8. One can refer to its article published in Politique étrangère. Maurice Bertrand, "Le concept de prévention des conflits," Politique étrangère, avril 1997.

9. According to Michael Lund, preventive diplomacy requires a narrower definition than the one commonly offered in international institutions circles which tend to confuse the concept with one of conflict management. "... equating preventive diplomacy with large portions of international relations and national policy is to dismiss the concept, for a definition that embraces everything means nothing ... A more rigorous definition should pinpoint the essence of the concept and distinguish it from other forms of diplomacy, foreign policy and conflict prevention." Michael Lund, Preventing Violent Conflicts, 32.

10. Maurice Bertrand, op. cit.

11. The desire of some East European states to join the Union and the West in general, pushes them to have a compromising attitude toward their minority problem and to see the help of the OSCE to manage the conflicting situations in which they are in. Maurice Bertrand, "Le concept de 'prévention des conflits'", Politique étrangère, avril 1997. ם



Refuge, Vol. 16, No. 1 (May 1997) 